\title{
Differential effects of plant root systems on nickel, copper and silver bioavailability in contaminated soil
}

\author{
Thi Xuan Trang Nguyen ${ }^{1,2}$, Marc Amyot ${ }^{2}$ and Michel Labrecque ${ }^{1, *}$ \\ ${ }^{1}$ Institut de recherche en biologie végétale, Université de Montréal, 4101 \\ Sherbrooke East Montreal, Qc, Canada, H1X 2B2 \\ ${ }^{2}$ Département de sciences biologiques, Université de Montréal, 90 Vincent d'Indy, \\ Montréal, Québec, H3C 3J7, Canada
}

*Corresponding Author: M. Labrecque. Institut de recherche en biologie végétale, Université de Montréal and Montreal Botanical Garden, 4101 Sherbrooke East, Montreal, QC H1X 2B2, Canada Phone 001514872 1862. E-mail: michel.labrecque@umontreal.ca 


\title{
Highlights
}

The labile pools of TE, notably $\mathrm{Ag}, \mathrm{Ni}$, and $\mathrm{Cu}$, were differently affected by the presence of the plants.

Availability of $\mathrm{Ni}$ and $\mathrm{Cu}$ is related to the level of dissolved organic carbon (DOC) in the soil.

Different root systems can have a distinct influence on soil DOC, and thus can modify the labile pools of $\mathrm{Ni}$ and $\mathrm{Cu}$.

\begin{abstract}
A pot experiment was conducted to investigate the effect of diverse plant species (four herbaceous and four woody species) on the labile pool of six metals $(\mathrm{Ag}, \mathrm{Cu}, \mathrm{Pd}, \mathrm{Zn}, \mathrm{Ni}$ and $\mathrm{Se})$ present in their rhizosphere. After three months of cultivation, concentrations of trace elements (TE) in above and below-ground biomass of each species were determined. The labile and presumably bioavailable fraction of these TE in the rhizosphere as well as key soil parameters (e.g. pH, electrical conductivity (EC), percent of organic matter and dissolved organic carbon (DOC)) were also measured and compared as a function of plant species. The concentration of TE in plant tissues differed among species. In general and as expected, concentrations were higher in root tissues of tested plants than in above-ground tissues. While the labile pool of several TE in the rhizosphere, notably $\mathrm{Ag}, \mathrm{Ni}$, and $\mathrm{Cu}$, was significantly and differently affected by the presence of the plants, $\mathrm{pH}, \mathrm{EC}$ and percentage of organic matter remained unchanged. In contrast, DOC was higher in the rhizosphere of all tested plants than in soil of the control pots without plants. In addition, there was a positive relationship between $\mathrm{Ni}$ and $\mathrm{Cu}$ availability concentrations, and DOC levels. This suggests that root systems of different species can have a distinct influence on soil DOC and consequently modify the labile pools of $\mathrm{Ni}$ and $\mathrm{Cu}$ in the rhizosphere. These findings have important implications for plant selection in phytoremediation projects.
\end{abstract}

\section{KEYWORDS:}

Bioavailability, trace elements, rhizosphere, dissolved organic carbon

$\begin{array}{ll}\text { Abbreviations } & \\ \text { TE } & \text { Trace elements } \\ \text { EC } & \text { Electrical conductivity } \\ \text { DOC } & \text { Dissolved organic carbon }\end{array}$




\section{INTRODUCTION}

Labile pools of contaminants are usually considered to be biologically active (bioavailable) and soluble (mobile) in the matrix (Mench et al., 2009). They represent a fraction of the total contaminant pool; the remainder corresponds to the non-labile forms. The balance between these forms varies according to soil conditions such as pH, redox potential and the presence of organic ligands (NFESC, 2000; Schwartz et al., 2003). Therefore, bioavailability of TE can influence the efficiency of metal phytoextraction in metalcontaminated soil. The bioavailability of metals in soils depends on many factors, including their speciation (Salomons, 1995; NFESC, 2000), pH, organic matter content, cation exchange capacity and soil texture (Reichman, 2002; Jung, 2008; Violante et al., 2010; Fijałkowski et al., 2012). Some plant species, identified as hyperaccumulator plants, can concentrate and tolerate high levels of metals in their tissues due to their specific capacity for metal uptake and accumulation in detoxified subcellular fractions such as granules (Tu et al., 2004; Peer et al., 2006). In addition, TE bioavailability can be enhanced by using chelating agents such as ethylene diamine tetraacetic acid (EDTA) (Blaylock et al., 1997; Vassil et al., 1998; Kos and Leštan, 2004; Hernández et al., 2007; Surat et al., 2008; Suthar et al., 2014; Baek et al., 2005), humic acids (HA) (Evangelou et al., 2004; Topcuoğlu, 2012) and diethylene triamine pentaacetic acid (DTPA) (Zhao et al., 2007; Li et al., 2011), or by lowering soil pH using chemicals (e.g. elemental sulfur, aluminum sulfate, iron sulfate) (Everhart, 1994; Vossen, 2006; Longstroth, 2008). However, disadvantages of these methods are that synthetic chelators, such as EDTA, are barely degradable by microorganisms and their use on an operational basis can pose an environmental risk, especially to ground water (Chen et al., 2004). Also, lowering soil $\mathrm{pH}$ is a slow process and may require repeated treatments. Furthermore, the repeated application of aluminum or iron can result in a build-up of these metals in the soil up to toxic levels (Vossen, 2006). For these reasons, it is important to better understand how plant root systems could positively influence both the soil rhizosphere and the labile pool of metals.

The use of plants for remediating metal-contaminated soil has been subjected to extensive studies. Numerous investigations have focused on the use of hyperaccumulators and fast growing plants or secondary accumulator plant species to absorb and concentrate TE in their tissues (Koontz and Berle, 1980; 
Hammer et al., 2003; Yanqun et al., 2003; Solhi et al., 2005; Chen et al., 2009; Soudek et al., 2010). These studies have proposed effective solutions for removal of TE from soil. Some studies have also addressed the role of roots in the phytoremediation of inorganic contaminants such as metals (McGrath et al., 2001;Fitz and Wenzel, 2002; Wenzel et al., 2004). From an operational point of view, some concerns remain regarding the use of exotic plants for phytoremediation. This is one of the reasons this study utilized different shrubs and herbaceous species indigenous to Eastern Canada. We also believe that perennial plant species are easier to manage, notably when repeated harvesting is involved, as in the case of phytoextraction of trace elements. Plants selected for this study have been shown to be easy to cultivate on harsh sites such as brownfields, and resprout well after coppicing or after mowing

The present study was undertaken to acquire knowledge on the effect of roots of different plant species on metal bioavailability in the soil. Consequently, this study aims to verify whether diverse plant species, characterized by different root systems, and physiological and nutritional demands, can positively influence both the rhizosphere and the labile pool of metals in soil. We propose two objectives: (1) to compare the levels of TE accumulated in different tissues of selected woody and herbaceous plant species; and (2) to compare the efficiency of these species in terms of their capacity to affect metal bioavailability in a TE polluted soil.

\section{MATERIALS AND METHODS}

\section{Experimental design}

A pot experiment examined eight plant species, which included the four woody species Salix nigra, Populus sp, Cornus stolonifera, Alnus crispa, and the four herbaceous species Phalaris arundinacea, Trifolium repens, Panicum virgatum, Festuca arundinacea. These species have all been commonly used in the context of phytoextraction studies in Canada (Pitre et al., 2010; Guidi Nissim et al., 2014; Guidi Nissim et al., 2015).

The four woody species selected were young seedlings produced in "Styroblock ®" containers and transplanted into pots containing the polluted soil (one seedling per pot). The herb species were seeded directly in the pots (10 grams of seed per pot). During plant growth, only tap water (125 ml per day) was 
supplied by an automatic drip irrigation system, without the addition of fertilizers or any other amendments.

The soil used in this experiment was excavated from a brownfield located in an industrial zone in the

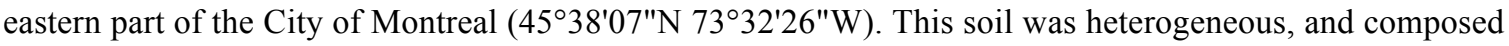
of filled material including gravel, sand and less than $3 \%$ organic material. Large stones and debris were removed from the soil, which was then thoroughly mixed and homogenized and used to fill the pots. A complete portrait of the chemical and agronomic characteristics is shown in Table 1. The trace element content was not considered very high, and silver was the only metal that could be considered an environmental risk according to the provincial guidelines used in Quebec, Canada (Beaulieu, 2016). The concentrations of zinc, copper and nickel were close to but not above levels considered acceptable (Table 1). This trial was carried out under a polyethylene transparent roof (to avoid interference from natural precipitation) mounted on a tunnel structure on the site of the Montreal Botanical Garden, Montreal, Canada $\left(45^{\circ} 55^{\prime} 72^{\prime}\right.$ ' $\left.\mathrm{N}, 73^{\circ} 55^{\prime} 68^{\prime \prime} \mathrm{W}\right)$. The cultivation period lasted for three months during summer, from June $6^{\text {th }}$ to September $3^{\text {rd }}, 2014$. Five-liter plastic pots were installed in a completely randomized block design with five replicates. Each block included the eight species planted in two pots (plus one control pot without any plants) for a total of 85 pots.

\section{Chemical analysis}

\section{Sampling}

Plants were harvested by cutting the above-ground tissues at the soil surface and removing the roots from the pots. Rhizosphere soil, the soil adhering to plant roots (Jaillard et al., 2002), was collected after gently shaking the roots. Soil samples were placed in plastic bags and air dried for several days until analysis. Roots were thoroughly washed in tap water, then quickly rinsed in deionized water, to remove adhering soil particles. Above-ground tissues and cleaned roots were oven-dried at $70{ }^{0} \mathrm{C}$ until they reached a constant weight. 


\section{Soil analyses}

Chemical properties of the soil used for planting were determined based on analysis of five random samples taken prior to filling the pots. Soil $\mathrm{pH}$ was measured in deionised water at a 1:1 soil:water ratio (Hendershot et al. 2008). Electric conductivity (EC) was determined following the CEAEQ method (CEAQ 2015). Total organic matter was obtained by loss on ignition following the Rabenhorst (1988) method. Cation-exchange capacity (CEC) was estimated with the $\mathrm{BaCl}_{2}$ displacement method used by Hendershot et al. (2008). A hot acid-extractable method was used to estimate soil TE concentrations. A $200 \mathrm{mg}$ mass of $0.5 \mathrm{~mm}$ sieved dry soil was soaked overnight in $2 \mathrm{~mL}$ of concentrated nitric acid (trace metal grade, $\mathrm{HNO}_{3}$ ) in $16 \times 125 \mathrm{~mm}$ Pyrex ignition tubes. Samples were digested on a block digester at a mean temperature of $120^{\circ} \mathrm{C}$ for $5 \mathrm{~h}$. The volume was adjusted to $50 \mathrm{~mL}$ with deionized water and suspensions were filtered through a Nylon membrane $(0.45-\mu \mathrm{m})$. The suspension reacted on a reciprocal shaker for two hours, was centrifuged $(1400$ g) for 10 min, filtered with a Nylon membrane $(0.45-\mu \mathrm{m})$ and stored in $0.2 \%$ trace metal grade HNO3. The TE concentrations of $\mathrm{HNO}_{3}$ extracts were measured by ICP-mass spectrometry using appropriate dilution to reduce matrix effects (Perkin Elmer NexION 300).

\section{Metal bioavailability}

Water extraction was used to estimate water-soluble TE in the soil. Soluble metal concentrations are typically well correlated with plant uptake (Ivezić et al., 2013). Metals present in the water extract are considered water-soluble and potentially available for uptake, or bioavailable (Séguin et al., 2004).

Water extraction involved adding $40 \mathrm{ml}$ of deionized $\mathrm{H}_{2} \mathrm{O}$ and a 4 g soil sample (sieved through a $0.5 \mathrm{~mm}$ mesh) into a $50 \mathrm{ml}$ acid-washed Falcon ${ }^{\circledR}$ tube. The tubes were then shaken end-over-end for 2 hours at room temperature. Subsequently, the samples were centrifuged at $1400 \mathrm{~g}$ for 15 minutes. The mixture was then filtered through a nylon membrane (pore size $0.45 \mu \mathrm{m}$ ) using a vacuum system. $0.02 \mathrm{ml} \mathrm{HNO}_{3} 50 \%$ (TMG grade, Thermo-Fisher) was then added to $5 \mathrm{ml}$ samples of the filtered solution. As for $\mathrm{HNO}_{3}$ extracts described above, an ICP-mass spectrometer (Perkin ElmerNexION 300) was used for analysis of watersoluble TE (referred to as Ag- $\mathrm{H}_{2} \mathrm{O}, \mathrm{Se}-\mathrm{H}_{2} \mathrm{O}, \mathrm{Cu}-\mathrm{H}_{2} \mathrm{O}, \mathrm{Ni}-\mathrm{H}_{2} \mathrm{O}, \mathrm{Pb}-\mathrm{H}_{2} \mathrm{O}$, and $\mathrm{Zn}-\mathrm{H}_{2} \mathrm{O}$ ). 


\section{Plant tissue digestion}

Dry plant tissue samples $(0.200 \mathrm{~g})$ were digested in borosilicate tubes containing $2 \mathrm{ml}$ nitric acid $70 \%$ (TMG grade from Thermo-Fisher) at $120^{\circ} \mathrm{C}$ for five hours. The entire contents of the borosilicate tubes were transferred into $50 \mathrm{ml}$ Falcon ${ }^{\circledR}$ tubes and the volumes were adjusted to $50 \mathrm{ml}$ with ultrapure water (MilliQ), to attain a final concentration of $4 \%$ nitric acid. The tubes were stirred and allowed to stand overnight. Samples were then filtered through a nylon membrane (pore size $0.45 \mu \mathrm{m}$ ). Digestates were diluted to $2 \% \mathrm{HNO}_{3}$ before ICP-MS analyses.

\section{Quality assurance and quality control for metal analyses}

Laboratory equipment was acid-washed $\left(20 \% \mathrm{HNO}_{3}\right)$ and rinsed six times with deionized water. Quality controls were performed with certified natural water from the National Institute of Standards and Technology (NIST 1640a). The results yielded mean recoveries of $99-102 \%$ for all metals.

For the soil water extractions and other soil physicochemical measurements, internal soil control was used to test quality. The results yielded an accuracy of $82-133 \%$. The detection limit of the method was calculated for each environmental matrix by multiplying by three the standard deviation obtained from multiple analyses of solutions having low solute concentrations $(0.0008-0.2414 \mu \mathrm{g} / \mathrm{l}$, depending on the TE).

DOC analysis

DOC concentrations were measured with an IO Aurora 1030 carbon analyzer. Briefly, DIC (dissolved inorganic carbon) was purged from samples after adding phosphoric acid (5\% ACS grade, Fisher Scientific). DOC was oxidized by adding sodium persulfate, $10 \%(98 \%+$ grade, Acros $)$ and quantified against a potassium biphtalate (BDH) calibration curve $(0-25 \mathrm{mg} / \mathrm{L})$.

\section{Statistical analysis}

All variables were analyzed with fixed-model ANOVAs. This model is presented as $\mathrm{Y}=$ blocks.species.blocks*species, in which Y represents variables measured $(\mathrm{pH}, \mathrm{EC}$, percent organic matter, DOC, TE in the soil and TE in the plants), and blocks and species are nominal variables. For all tests, the 
classical level of 0.05 was used as $p$-value threshold. Analyses were performed using JMP statistical software version 10.0 (SAS Institute, Cary, NC) and Excel (Microsoft Inc.) software packages.

\section{RESULTS}

\section{Biomass}

Total biomass varied between $4.6 \mathrm{~g} \mathrm{pot}^{-1}$ to $16.8 \mathrm{~g} \mathrm{pot}^{-1}$ for $A$. crispa and P. virgatum, respectively. Root biomass ranged from $1.4 \mathrm{~g} \mathrm{pot}^{-1}$ in $A$. crispa to $7.3 \mathrm{~g} \mathrm{pot}^{-1}$ in $F$. arundinacea and from $3.3 \mathrm{~g} \mathrm{pot}^{-1}$ in $A$. crispa to $11.7 \mathrm{~g} \mathrm{pot}^{-1}$ in T. repens for above-ground biomass (Figure 1). The largest root biomass was found for $F$. arundinacea, and P. virgatum. Above-ground tissue biomass was found to be highest in T. repens, and was three times higher than in A. crispa.

Among the eight plant species, A. crispa had the smallest biomass, which necessarily affects its capacity to accumulate metals. For example, Ni mass per pot in roots $A$. crispa (i.e., TE concentration $\times$ biomass) was $0.2 \mathrm{mg} \mathrm{pot}^{-1}$, while roots of $T$. repens was able to take up $0.7 \mathrm{mg} \mathrm{pot}^{-1}$.

$A g, P b, C u, Z n, N i$, Se in roots and above-ground tissues.

All tested species showed a low Ag concentration in their above-ground tissues (stem, leaves and twigs) (Figure 2A). The highest concentrations were observed in roots of $F$. arundinacea and $P$. arundinacea $(\mathrm{P}<$ $0.05)$.

$\mathrm{Cu}$ concentrations in roots varied between $34.5 \mathrm{mg} \mathrm{kg}^{-1}$ (in A. crispa) and $292.7 \mathrm{mg} \mathrm{kg}^{-1}$ (in $P$. arundinacea). $\mathrm{P}$ arundinacea also presented the highest $\mathrm{Cu}$ concentration $(\mathrm{P}<0.05)$ in its above-ground tissues with a value of $55.8 \mathrm{mg} \mathrm{kg}-1$ (Figure 2B). (Figure 2B).

$\mathrm{Zn}$ translocation to above-ground tissues of $S$. nigra was the greatest $\left(159.9 \mathrm{mg} \mathrm{kg}^{-1}\right)$, followed by $P$. arundinacea (104.4 mg kg-1) and Populus sp. (96.2 mg kg-1), while the lowest value was found in $C$. stolonifera $\left(32.8 \mathrm{mg} \mathrm{kg}^{-1}\right)$; the corresponding $\mathrm{Zn}$ concentrations in roots varied between $62.7 \mathrm{mg} \mathrm{kg}^{-1}$ (in $A$. crispa) and $212.4 \pm 14.0 \mathrm{mg} \mathrm{kg}^{-1}$ (in S. nigra) (Figure 2C).

Figure 2D shows that Ni concentrations in above-ground tissues were generally low and inferior to $3 \mathrm{mg}$

$\mathrm{kg}^{-1}$ ). Concentration in the roots was about twice that found in aerial parts, with the highest value found in T. repens $\left(4.7 \mathrm{mg} \mathrm{kg}^{-1}\right)$. 
$\mathrm{Pb}$ concentrations in aerial parts were also low for all species. The highest concentration was observed in $P$. arundinacea $\left(2.72 \mathrm{mg} \mathrm{kg}^{-1}\right)$. In root tissues, C. stolonifera had the highest level of $\mathrm{Pb}\left(6.77 \mathrm{mg} \mathrm{kg}^{-1}\right)$. The lowest $\mathrm{Pb}$ concentrations were in root tissues of $P$. virgatum and A. crispa $(2.05$ and 2.46 respectively)(Figure 2E).

Se accumulation was found to be highest in the above-ground tissues of the two grass species, $F$. arundinacea and P. arundinacea but the concentrations were weak and did not exceed $0.25 \mathrm{mg} \mathrm{kg}^{-1}$ (Figure 2F).

In general, these results indicate that TE accumulation by plants differed among species and tissues. In addition, concentrations of TE accumulated by plants were mostly accumulated in roots. However the ratios between $\mathrm{Ni}$ and $\mathrm{Zn}$ concentrations in aerial to belowground tissues were higher in comparison to other TE. TE concentrations $\left(\mathrm{mg} \mathrm{kg}^{-1}\right)$ in root tissues of the herb species tended to be greater than in those of the woody species because herb species grew faster, and their root system was more extensive than that of the woody species. Therefore, total TE removal (i.e., TE concentration $\times$ biomass) in herb species was greater than woody species. For example, $\mathrm{Se}, \mathrm{Zn}, \mathrm{Cu}$, and $\mathrm{Ni}$ taken up by $T$. repens were $4.1 \mathrm{mg}, 2.7 \mathrm{mg}, 1.4 \mathrm{mg}$, and $1.4 \mathrm{mg}$ respectively. On the other hand, quantities of $\mathrm{Se}, \mathrm{Zn}, \mathrm{Cu}$, and $\mathrm{Ni}$ found in biomass of $A$. crispa were only $0.3 \mathrm{mg}, 0.2 \mathrm{mg}, 0.1 \mathrm{mg}$, and $0.1 \mathrm{mg}$ respectively (data not shown).

In general, water-extractable fraction (considered to be potentially available for uptake) of TE was higher in rhizospheric soil than in unplanted control soil (Figure 3). For instance, Ag concentration in the waterextractable fraction in the rhizosphere was the highest in rhizosphere of $S$. nigra (Figure 3). Available concentrations of $\mathrm{Cu}$ were found to be greater in the rhizosphere of three herb species, namely T. repens, F. arundinacea and $P$. virgatum. It was not possible to observe a similar pattern for $\mathrm{Ni}$ and $\mathrm{Cu}$ (Figure 3).

$E C, p H$, and \% organic matter, and DOC

Measurements were made to evaluate whether the cultivation of plants can induce some changes in $\mathrm{EC}, \mathrm{pH}$, and $\%$ organic matter in the rhizospheres of all species. No significant changes were observed for any of these particular parameters (data not shown).

In contrast, DOC levels in the rhizosphere of T. repens $\left(6.7 \mathrm{mg} \mathrm{l}^{-1}\right)$ and C. stolonifera $\left(6.3 \mathrm{mg}^{-1}\right)$ were significantly different from that measured in the control pots $\left(4.7 \mathrm{mg}^{-1}\right)$ (Table 2). 
Figure 4 presents changes in TE bioavailability according to the level of DOC measured in the soils. Only the most relevant results are shown in this figure. DOC in the rhizosphere of S. nigra was at an intermediate level compared to the rhizosphere of the other species, but the available concentration of Ag was highest. However, the highest DOC level as well as the highest concentrations of available $\mathrm{Ni}$ and $\mathrm{Cu}$ were found in the rhizosphere of T. repens.

After three months of plant growth, there was a positive and statistically significant correlation between the availability of $\mathrm{Ni}$ (adjusted $\mathrm{R}^{2}=0.67 ; \mathrm{p}=0.004$ ) and $\mathrm{Cu}$ (adjusted $\mathrm{R}^{2}=0.59 ; \mathrm{p}=0.009$ ), and DOC concentrations in the rhizosphere (Figure 4, Table 3). In the case of Ag, no significant relationship was found, even when excluding the extreme value of S. nigra. This suggests that different root systems had different abilities to directly affect DOC levels in the rhizosphere, and to indirectly influence the availability of $\mathrm{Ni}$ and $\mathrm{Cu}$ in the rhizosphere.

\section{DISCUSSION}

\section{Concentrations of TE in tissues}

The capacity of the plants in this experiment to absorb TE in their tissues was investigated. Ag rarely occurs in nature in a soluble form (Koontz and Berle, 1980), so available Ag for plant uptake is restricted.

In this study, Ag concentration in soil was only $2.4 \mathrm{mg} \mathrm{kg}^{-1}$, but concentrations of Ag accumulated in root tissues of $F$. arundinacea were up to $1.7 \mathrm{mg} \mathrm{kg}^{-1}$. Ag was mainly stored and immobilized in the root, which suggests that $F$. arundinacea has potential for use in phytostabilization of Ag-contaminated soils (USEPA, 1999).

Among the TE tested in this experiment, $\mathrm{Zn}$ and $\mathrm{Ni}$ were translocated to aerial tissues in greatest amounts. S. nigra was more efficient than other species at translocating $\mathrm{Zn}$ from root to shoot tissues. Therefore, the efficient removal of $\mathrm{Zn}$ from the soil-plant system could be achieved through the harvest of aerial plant parts. Based on our findings, S. nigra would be a good candidate for use in phytoextraction in $\mathrm{Zn}$ contaminated soils.

Se is a metalloid that can be lost to the atmosphere because it can be biomethylated to form volatile molecules (Guidi Nissim et al., 2015). Some plants, such as Astragalus bisculatus (Neuhierl and Bock, 1996), Atriplex nummularia and Brassica juncea (Smith, 1994), have been found to accumulate high 
amounts of Se (up to several milligrams/gram dry tissue) by accumulating nonvolatile methyl selenate derivatives. In the current study, the highest accumulation of Se was in the roots of S. nigra, which reached $0.32 \mathrm{mg} \mathrm{kg}{ }^{-1}$, and in above-ground tissues of $F$. arundinacea and $P$. arundinacea with concentrations around $0,25 \mathrm{mg} \mathrm{kg}^{-1}$ although its concentration in soil was very low, with less than $1.0 \mathrm{mg} \mathrm{kg}^{-1}$.

$\mathrm{Cu}$ is an element known to be essential to plant growth, however it can become toxic when it accumulates in shoots or leaves at levels exceeding $20 \mathrm{mg} \mathrm{kg}^{-1}$ (Krämer et al., 1997). Cu values in this study were above this toxic level in some tested species such as P. arundinacea $\left(55.8 \mathrm{mg} \mathrm{kg}^{-1}\right)$, T. repens $\left(41.8 \mathrm{mg} \mathrm{kg}^{-1}\right)$, and P. virgatum $\left(29.4 \mathrm{mg} \mathrm{kg}^{-1}\right)$. These plant species may have good potential for use in remediation of $\mathrm{Cu}-$ contaminated soils, since they were able to tolerate high $\mathrm{Cu}$ levels.

In soil, $\mathrm{Pb}$ usually exists as insoluble precipitates (phosphates, carbonates and hydroxyoxides), which are largely unavailable for uptake by roots; the potential for $\mathrm{Pb}$ phytoextraction is therefore limited (Lasat, 2002). $\mathrm{Pb}$ accumulation was relatively higher in roots than in above-ground tissues for all tested plant species. This trend was similar to those found for other species. For instance, $\mathrm{Pb}$ accumulated in sunflower (hybrid Albena) that grew in soil that contained $554 \mathrm{mg} \mathrm{kg}^{-1} \mathrm{~Pb}$ as follows: $38.9 \mathrm{mg} \mathrm{kg}^{-1}$ in roots, $22.6 \mathrm{mg}$ $\mathrm{kg}^{-1}$ in shoots, $4.3 \mathrm{mg} \mathrm{kg}^{-1}$ in leaves, $1.7 \mathrm{mg} \mathrm{kg}^{-1}$ in capsules, and $11.6 \mathrm{mg} \mathrm{kg}^{-1}$ in seeds (Lasat et al., 1998).

\section{Availability of TE in the rhizozphere}

Overall, the presence of plant species did not affect most measured parameters $(\mathrm{pH}, \mathrm{EC}$, percent organic matter), they did, however, affect DOC levels.

Regarding $\mathrm{pH}$, various researchers have found that metal solubility increases greatly under acidic conditions (Harter, 1983; Chuan et al., 1996; Takáč et al., 2009). With increasing pH, the availability of most metals present in soil decreases due to their increased adsorption and precipitation in alkaline media (Takáč et al., 2009). Smith (1994) found a negative relationship between concentrations of $\mathrm{Ni}$ and $\mathrm{Cu}$ in ryegrass and soil $\mathrm{pH}$ (ranging from 4.2- to 7.0) ). In this study, soil $\mathrm{pH}$ was more alkaline, ranging from 7.94 to 8.00 . This indicates that the solubility of all the elements was likely limited by $\mathrm{pH}$. The highest available concentrations of $\mathrm{Ag}, \mathrm{Cu}$ and $\mathrm{Ni}$ were $1 \mu \mathrm{g} \mathrm{kg}^{-1}$ in $S$. nigra, $200.4 \mu \mathrm{g} \mathrm{kg}^{-1}$ and $32.3 \mu \mathrm{g} \mathrm{kg}^{-1}$ in $T$. repens, respectively. It is likely that the very narrow range of $\mathrm{pH}$ values precluded the detection of a relationship between $\mathrm{pH}$ and metal availability. 
In contrast, we found strong and significant linear relationships between DOC and metal availability in the rhizosphere. Metals can form complexes with DOC (Welsh, 1996; Zhao et al., 2007; Merrington and Peters, 2009), and these complexes may increase the labile metal pool and thus also metal bioavailability (Rembe and Trefry, 2003 Antoniadis and Alloway, 2001; Carmona et al., 2008; Li et al., 2011). A previous study found that plants significantly increase the size of a number of dissolved nutrient pools, which include DOC and total phenolics in solution (Khalida et al., 2006). It is interesting to note that some studies have also shown that hyperaccumulator species exude more DOC in the rhizosphere than nonhyperaccumulators (Tu et al., 2004; Li et al., 2011). These results provide support to the hypothesis that certain plants may enhance metal solubility in the rhizosphere via root exudation, consequently increasing plant metal uptake (Li et al., 2011). This increased metal availability may either result directly from the formation of complexes between metals and organic ligand exudates, or it can be an indirect process by which root exudates in the form of organic acids destabilize metal bounds in the soil organic matter, making these metals available for uptake (Clarholm et al, 2015).

In this study, DOC concentrations were also significantly and differently affected by the presence of plants, with the lowest DOC levels found in the unplanted treatment. There was no clear difference between wood vs herbaceous species in their ability to modify DOC levels in rhizosphere. Positive relationships were found between the availability concentration of $\mathrm{Ni}$ and $\mathrm{Cu}$, and $\mathrm{DOC}$ concentrations in the rhizosphere. This suggests that different root systems had different abilities to directly affect DOC pools in the soil and hence indirectly influence the bioavailable pool of TE and their uptake by roots. Further, this effect of plants on metal uptake is likely metal dependent, since we did not see a clear positive relationship between DOC and available Ag. This is to be anticipated, since different metal complexes will differ in solubility and will interact with metal binding sites on the root surface differently. There are few data in the published literature showing such relationships between DOC and available metals in the rhizosphere across many plant taxa, and further research should aim to identify what are the key metal complexes formed, and if the effect of root exudates is mainly via direct complexation or by metal destabilization of the soil organic matter. This would enhance our ability to predict metal uptake by plants. Our findings suggest that knowledge of the phytoremediation potential of the root systems of 
individual species can significantly improve the outcome of phytoremediation projects, but ensuring that plant selection accommodates the needs specific to a project, whether phytostabilization or phytoextraction.

\section{ACKNOWLEDGMENTS}

This study was supported by the NSERC CREATE Mine of Knowledge program through a scholarship to Nguyen Thi Xuan Trang. We would like to thank Golder and Associates for their partnership in funding this research program. The authors also wish to thank Marie-Claude Turmel and Dominic Bélanger for skillful technical assistance in the laboratory; Kadri Hafssa and Ahmed Jerbi for assistance in the field. We gratefully acknowledge advice from Professors François Courchesne and Frédéric Pitre for the experimental set-up as well as elemental analyses. M.A. received support from the Canada Research Chair and NSERC Discovery programs.

\section{REFERENCES}

Antoniadis V, Alloway B J 2001 The role of dissolved organic carbon in the mobility of $\mathrm{Cd}, \mathrm{Ni}$ and $\mathrm{Zn}$ in sewage sludge - amended soils. Environmental Pollution. 117, 515-521.

Baek K H, Kim H H, Bae B, Chang Y Y, Lee I S 2005 EDTA-assisted phytoextraction of lead from leadcontaminated soils by Echinochloa crusgalli var. frumentacea. Journal of Environmental Biology. 26(1), 151-154.

Beaulieu M. 2016 Protection des sols et réhabilitation des terrains contaminés. Guide d'intervention. . Ministère du Développement durable, de l'Environnement et de la Lutte contre les changements climatiques. Gouvernement du Québec. 192 p.

Blaylock M J, Salt D E, Dushenkov S, Zakharova O, Gussman C, Kapulnik Y 1997 Enhanced accumulation of $\mathrm{Pb}$ in Indian mustard by soil-applied chelating agents. Environmental Science and Technology. 31, 860-865.

Carmona D M, Cano Á F, Arocena J M 2008 Dissolved organic carbon and metals release in amended soils. Resumen Workshop Macla. 10, 115-117.

Centre d'expertise en analyse environnementale du Québec 2015 Détermination de la conductivité : méthode électrométrique, MA 115 - Cond. 1.1, rév. 1, Ministère du Développement durable, de l'Environnement et de la Lutte contre les changements climatiques. 9 p. 
Clarholm M, Skyllberg U, Rosling 2015 Organic acid induced release of nutrients from metalstabilized soil organic matter - The unbutton model. Soil Biol Biochem 84, 168-176.

Chen B D, Huang D, Liu J 2009 Functions and toxicity of nickel in plants: recent advances and future prospects. Clean. 37, $304-313$.

Chen B D, Shen H, Li Z, Feng G, Christie P 2004 Effects of EDTA application and arbuscular mycorrhizal colonization on growth and zinc uptake by maize (Zea mays L.) in soil experimentally contaminated with zinc. Plant and Soil. 261, 219-229.

Chuan M C, Shu G Y, Liu J C 1996 Solubility of heavy metals in a contaminated soil: effects of redox potential and pH. Water Air Soil Pollut. 91, 543-556.

Evangelou M W, H Daghan, A Schaeffer 2004 The influence of humic acids on the phytoextraction of cadmium from soil. Environmental Pollution. 132, 113-120.

Everhart E 1994 How To Change Your Soil's pH. Lowa State University of Science and Technology. $467(7), 42-43$.

Fijałkowski K, Kacprzak M, Grobelak A, Placek A 2012 The influence of selected soil parameters on the mobility of heavy metals in soil. In żynieriai Ochrona środowiska. 15 (1), 81-92.

Fitz W J, Wenzel W W 2002 Arsenic transformations in the soil-rhizosphere-plant system : fundamentals and potential application to phytoremediation. Journal of Biotechnology. 99, 259-278.

Guidi Nissim W, Hasbroucq S, Kadri H, Pitre F E, Labrecque M 2015 Potential of selected Canadian plant species for phytoextraction of trace elements from selenium-rich soil contaminated by industrial activity. International Journal of Phytoremediation (sous-presse).

Guidi Nissim W, Pitre F E, Kadri H, Desjardins D, Labrecque M 2014 Early response of willow to increasing silver concentration exposure. International Journal of Phytoremediation. 16(7-8), 660-670.

Hammer D, Kayser A, Keller C 2003 Phytoextraction of Cd and Zn with Salix viminalis in field trials. Soil Use and Management. 19, 187-192.

Harter R D 1983 Effect of soil pH on adsorption of lead, copper, zinc, and nickel. Soil Science Society of America Journal. 47, 47-51.

Hendershot W H, Lalande H, Duquette M. 2008 in Soil Sampling and Methods of Analysis, ed. M. R. Carter and E. G. Gregorich, Canadian Society of Soil Science, Florida, 2nd edn., ch. 16, pp. 173-178. 
Hernández A J, Garbisu C, Barrutia O, Becerril J M 2007 EDTA-induced heavy metal accumulation and phytotoxicity in cardoon plants. Environ Exp Bot 60, 26-32.

Ivezić V, Lončarić Z, Engler M, Kerovec D, Singh B R 2013 Comparison of different extraction methods representing available and total concentrations of $\mathrm{Cd}, \mathrm{Cu}, \mathrm{Fe}, \mathrm{Mn}$ and $\mathrm{Zn}$ in soil. PoljoPrivreda. 19, 53-58.

Jaillard B, Plassard C, Hinsinger P 2002 Measurements of H+ fluxes and concentrations in the rhizosphere. In Rengel Z. (Ed.). The handbook of soil acidity, Marcel Dekker,

Jung M C 2008 Heavy Metal Concentrations in Soils and Factors Affecting Metal Uptake by Plants in the Vicinity of a Korean Cu-W Mine. Sensors. 8, 2413-2423.

Khalida M., Solemana N., Jonesa D.L. 2006 Grassland plants affect dissolved organic carbon and nitrogen dynamics in soil. Soil Biology \& Biochemistry. 39, $378-381$.

Koontz H V, Berle K L 1980 Silver Uptake, Distribution, and Effect on Calcium, Phosphorus, and Sulfur Uptake. Plant Physiol. 65, 336-339.

Kos B., Leštan D. 2004 Chelator induced phytoextraction and in situ soil washing of Cu. Environmental Pollution. 132, 333-339.

Krämer U, Smith R D, Wenzel W W, Raskin I, Salt D E 1997 The role of metal transport and tolerance innickel hyperaccumulation by Thlaspi goesingense Hálácsy. Plant Physiol. 115(4), 1641-1650.

Lasat M M 2002 Phytoextraction of Toxic Metals: A Review of Biological Mechanisms. J.Environ. Qual. 31, 109-120.

Lasat M M, Baker A J M, Kochian L V 1998 Altered Zn compartmentation in the root symplasm and stimulated $\mathrm{Zn}$ absorption into the leaf as mechanisms involved in $\mathrm{Zn}$ hyperaccumulation in Thlaspi caerulescens. Plant Physiol. 118(3), 875-883.

Li T, Di Z, Yang X, Sparks D L 2011 Effects of dissolved organic matter from the rhizosphere of the hyperaccumulator Sedum alfredii on sorption of zinc and cadmium by different soils. Journal of Hazardous Materials. 192, 1616-1622.

Longstroth M 2008 Lowering Soil pH with Sulfur. Michigan State University Extension.

McGrath S P, Zhao F J, Lombi E 2001 Plant and rhizosphere processes involved in phytoremediation of metal contaminated soils. Plant Soil. 232, 207-214. 
Mench M, Schwitzguéb J B, Schroeder P, Bert V, Gawronski S, Gupta S 2009 Assessment of successful experiments and limitations of phytotechnologies: contaminant uptake, detoxification and sequestration, and consequences for food safety. Environ Sci Pollut. 16, 876-900.

Merrington G , Peters A 2009 The importance of dissolved organic carbon in the assessment of environmental quality standard compliance for copper and zin. Water Framework Directive-United Kingdom Technical Advisory Group (ISBN: 978-1 -906934-29-3).

Neuhierl B, Bock A 1996 On the mechanism of selenium tolerance in selenium-accumulating plants Purification and characterization of a specific selenocysteine methyltransferase from cultured cells of Astrugulus bisculatus. Eur. J. Biochem. 239, 235-238

NFESC Naval Facilities Engineering Service Center 2000 Guide for incorporating bioavailability adjustments into Human Health and Ecological Risk Assessments at US Navy and Marine Corps Facilities (Part 2: Technical Background Document for Assessing Metals Bioavailability). Prepared by Battelle and Exponent, Washington DC.

Peer W A, Baxter I R, Richards E L, Freeman J L, Murphy A S 2006 Phytoremediation and hyperaccumulator plants. Molecular Biology of Metal Homeostasis and Detoxification. Topics in Current Genetics. 14, 299-340.

Pitre F, Teodorescu T I, Labrecque M 2010 Brownfield phytoremediation of heavy metals using Brassica and Salix supplemented with EDTA: Results of the first growing season. Jour. of Environ. Science and Engi. 4, 51-59.

Rabenhorst M C 1988 Determination of Organic and Carbonate Carbon in Calcareous Soils Using Dry Combustion. Soil Science Society of America Journal. 52, 965-969.

Reichman S M 2002 The Responses of Plants to Metal Toxicity. A Review Focusing on Copper, Manganese and Zinc. Australian Minerals and Energy Environment Foundation, 14-59.

Rembe R D, Trefry J H 2003 Increased concentrations of dissolved trace metals and organic carbon during snowmelt in rivers of the Alaskan Arctic. Geochimica et Cosmochimica Acta. 68, 477-489.Schwartz C, Echevarria G, Morel J L 2003 Phytoextraction of cadmium with Thlaspi caerulescens Plant and Soil, 249, 27-35. 
Salomons W 1995 Environmental impact of metals derived from mining activities: processes, predictions, prevention. Geochem Explor. 52, 5-23.

Séguin V, Gagnon C, Courchesne F 2004 Changes in water extractable metals, pH and organic carbon concentrations at the soil-root interface of forested soils. Plant Soil. 260, 1-17.

Smith S R 1994 Effect of soil pH on availability to crops of metals in sewage sludgetreated soils. I. Nickel, copper and zinc uptake and toxicity to ryegrass. Environ Pollut. 85, 321-327.

Solhi M, Hajabbasi M A , Shareatmadari H 2005 Heavy Metals Extraction Potential of Sunflower (Helianthus annuus) and Canola (Brassica napus). Caspian J. Env. Sci. 3(1), 35-42.

Soudek P, Petrová Š, Benešová D , Vaněk T 2010 Phytoextraction of toxic metals by sunflower and corn plants. Journal of Food Agriculture \& Environment. 8 (3\&4), 383-390.

Surat W, Kruatrachue M, Pokethitiyook P, Tanhan P, Samranwanich T 2008 Potential of Sonchus Arvensis for the Phytoremediation of Lead-Contaminated Soil. Int J Phytorem 10, 325 - 342.

Suthar V, Memon K S, Mahmood-ul-Hassan M 2014 EDTA-enhanced phytoremediation of contaminated calcareous soils: heavy metal bioavailability, extractability, and uptake by maize and sesbania. Environ Monit Assess 186(6), 3957- 3968.

Takáč P, Szabová T, Kozáková L, Benková M 2009 Heavy metals and their bioavailability from soils in the long term polluted Central Spiš region of SR. Plant Soil Environment. 55, 167-172.

Topcuoğlu B 2012 The influence of humic acids on the metal bioavailability and phytoextraction efficiency in long-term sludge applied soil. Conference on International Research on Food Security, Natural Resource Management and Rural Development, Georg-August Universität Göttingen and University of Kassel-Witzenhausen, Germany.

Tu S, Ma L, Luongo T 2004 Root exudates and arsenic accumulation in arsenic hyperaccumulating Pteris vittata and non-hyperaccumulating Nephrolepis exaltata. Plant and Soil. 258, 9-19.

USEPA United States Environmental Protection Agency 1999 Phytoremediation Resource Guide.

Vassil A D, Kapulnik Y, Raskin I, Salt D E 1998 The Role of EDTA in Lead Transport and Accumulation by Indian Mustard. Plant Physiol. 117(2), 447-453.

Violante A, Cozzolino V, Perelomov L, Caporale A G, Pigna M 2010 Mobility and bioavailability of heavy metals and metalloids in soil environments. J. Soil Sci. Plant Nutr. 10(3), 268-292. 
Vossen P 2006 Changing pH in Soil. University of California Cooperative Extension.

Welsh P G 1996 Influence of dissolved organic carbon on the speciation, bioavailability and toxicity of metals to aquatic biota in soft water lakes. University of Waterloo.

Wenzel W W, Lombi E, Adriano D C 2004 Root and rhizosphere processes in metal hyperaccumulation and phytoremediation technology. In Heavy Metal Stress in Plants. pp. 313-344. Springer Berlin Heidelberg.

Yanqun Z, Yuan L, Schvartz C, Langlade L, Fan L 2003 Accumulation of Pb, Cd, Cu and Zn in plants and hyperaccumulator choice in Lanping lead-zinc mine area, China. Environ Int. 30(4), 567-576.

Zhao L Y L, Schulin R, Weng L, Nowack B 2007 Coupled mobilization of dissolved organic matter and tals $(\mathrm{Cu}$ and $\mathrm{Zn})$ in soil columns. Geochimica et Cosmochimica Acta. 71, 3407-3418. 
TABLES

Table 1. Characteristics and means of $\mathrm{HNO}_{3}$-extractable trace element concentrations of the soil used.

\begin{tabular}{lr}
\hline Characteristic & \multicolumn{1}{c}{ Mean } \\
\hline $\mathrm{pH}$ & $7.9 \pm 0.0$ \\
$\mathrm{EC}\left(\mu \mathrm{S} \mathrm{cm}^{-1}\right)$ & $131.0 \pm 7.0$ \\
$\mathrm{CaCO}_{3}(\%)$ & $34.4 \pm 1.4$ \\
$\mathrm{CEC}\left(\mathrm{meq} 100 \mathrm{~g}^{-1}\right)$ & $2.81 \pm 0.89$ \\
Organic-C $(\%)$ & $2.4 \pm 0.2$ \\
$\mathrm{Ag}\left(\mathrm{mg} \mathrm{kg}^{-1}\right)$ & $34.3 \pm 0.8$ \\
$\mathrm{Cu}\left(\mathrm{mg} \mathrm{kg}^{-1}\right)$ & $60.7 \pm 19.3$ \\
$\mathrm{~Pb}\left(\mathrm{mg} \mathrm{kg}^{-1}\right)$ & $129.9 \pm 2.1$ \\
$\mathrm{Zn}\left(\mathrm{mg} \mathrm{kg}^{-1}\right)$ & $29.9 \pm 4.2$ \\
$\mathrm{Ni}\left(\mathrm{mg} \mathrm{kg}^{-1}\right)$ & $0.9 \pm 0.1$ \\
$\mathrm{Se}\left(\mathrm{mg} \mathrm{kg}^{-1}\right)$ & \\
\hline
\end{tabular}


Table 2. Dissolved organic carbon in the rhizosphere of all plants after three months of in-pot cultivation

$$
\left(\mathrm{mg} \mathrm{l}^{-1}\right)
$$

\begin{tabular}{lr}
\hline Species & $\begin{array}{r}\text { Least Sq Mean } \\
\left(\mathrm{mg} \mathrm{l}^{-1}\right)\end{array}$ \\
\hline Trifolium rupens & $6.7^{(\mathrm{a})} \pm 0.3$ \\
Cornus stolonifera & $6.3^{(\mathrm{ab})} \pm 0.3$ \\
Festuca arundinacea & $6.1^{(\mathrm{abc})} \pm 0.3$ \\
Alnus crispa & $5.5^{(\mathrm{abc})} \pm 0.3$ \\
Panicum virgatum & $5.5^{(\mathrm{abc})} \pm 0.3$ \\
Phalaris & $5.3^{(\mathrm{abc})} \pm 0.3$ \\
arundinacea & $5.3^{(\mathrm{abc})} \pm 0.3$ \\
Salix nigra & $5.1^{(\mathrm{bc})} \pm 0.3$ \\
Populus sp & $4.7^{(\mathrm{c})} \pm 0.3$ \\
Unplanted control & \\
\hline
\end{tabular}

Different letters within the column indicate statistically significant differences between species, $\mathrm{P}<$ 0.05 . 
Table 3. Regression test relationship between the availability of $\mathrm{Ni}$ and $\mathrm{Cu}$, and $\mathrm{DOC}$ concentration in the rhizosphere after three months of cultivation in pots.

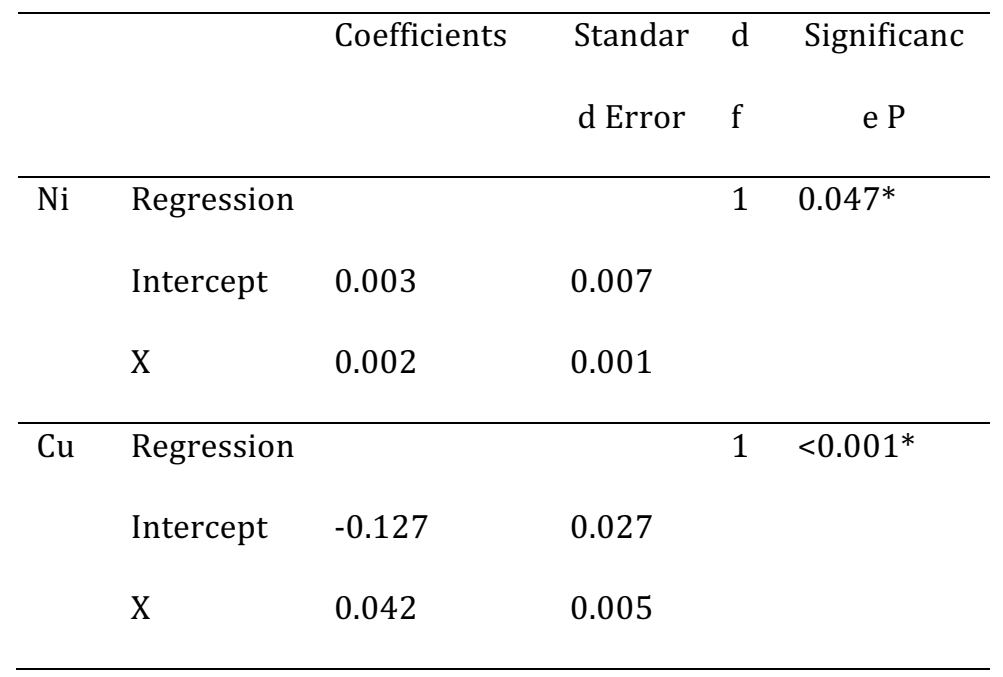

*: significance at level 5\%

$\mathrm{Y}\left(\mathrm{Ni}\right.$ availability concentration $\left.\left(\mathrm{mg} \mathrm{kg}^{-1}\right)\right)=0.002 \mathrm{X}\left(\mathrm{DOC}\right.$ concentration $\left.\left(\mathrm{mg} \mathrm{l}^{-1}\right)\right)+0.003$

$\mathrm{Y}\left(\mathrm{Cu}\right.$ availability concentration $\left.\left(\mathrm{mg} \mathrm{kg}^{-1}\right)\right)=0.042 \mathrm{X}\left(\mathrm{DOC}\right.$ concentration $\left.\left(\mathrm{mg} \mathrm{l}^{-1}\right)\right)-0.127$ 


\section{FIGURE CAPTIONS}

Figure 1. Comparison of biomass produced after three months of cultivation in pots. Columns with different letters are significantly different at $\mathrm{P}<0.05$.

Figure 2. The concentration of $\mathrm{TE}(\mathrm{Ag}, \mathrm{Ni}, \mathrm{Cu}, \mathrm{Pb}, \mathrm{Zn}$, and $\mathrm{Se})$ in roots and aboveground tissues of eight plant species after three months of cultivation in pots. Columns with different letters are significantly different at $\mathrm{P}<0.05$.

Figure 3. The water-soluble concentration of $\mathrm{TE}(\mathrm{Ag}, \mathrm{Ni}, \mathrm{Cu})$ in the rhizosphere of eight plant species after three months of cultivation in pots. Columns with different letters are significantly different at $\mathrm{P}<0.05$.

Figure 4. Changes in $\mathrm{TE}(\mathrm{Ag}, \mathrm{Ni}, \mathrm{Cu})$ bioavailability according to the level of $\mathrm{DOC}$ concentrations in the rhizosphere of eight plant species after three months of cultivation in pots. 
FIGURE 1. Nguyen et al.

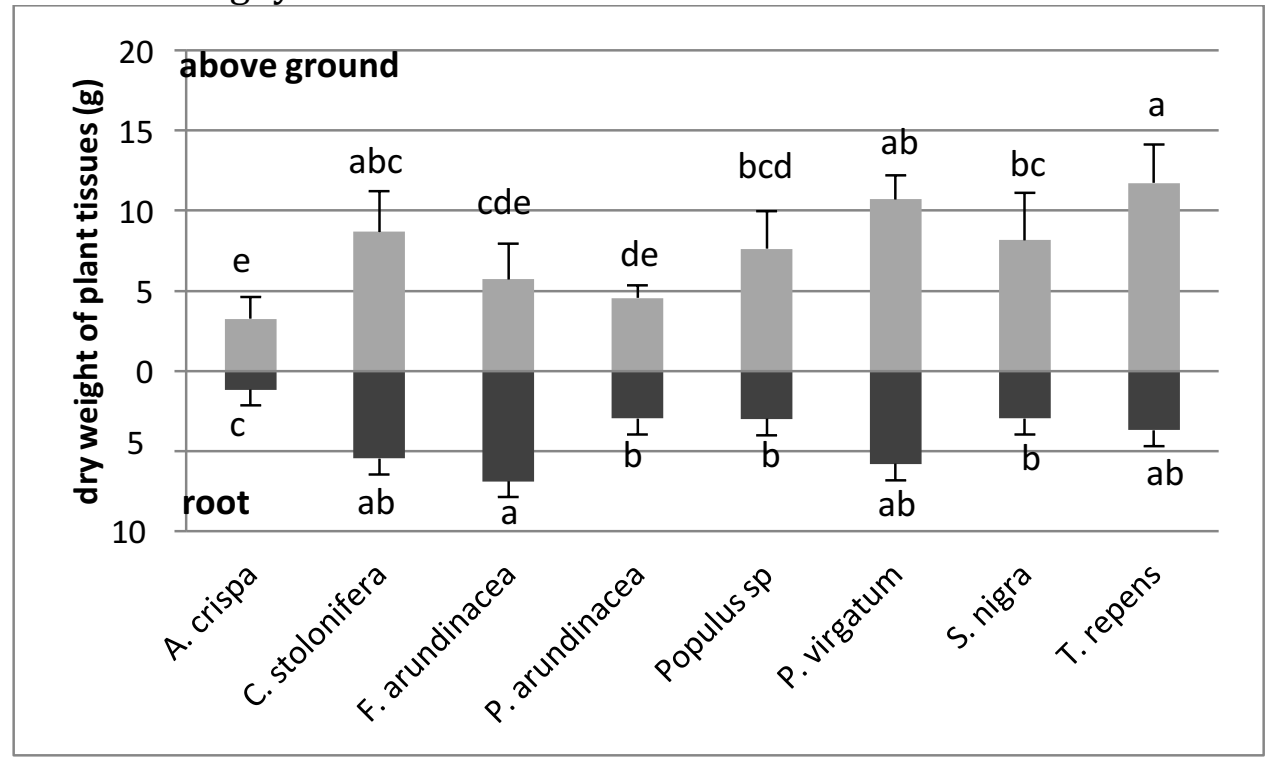


FIGURE 2. Nguyen et al.
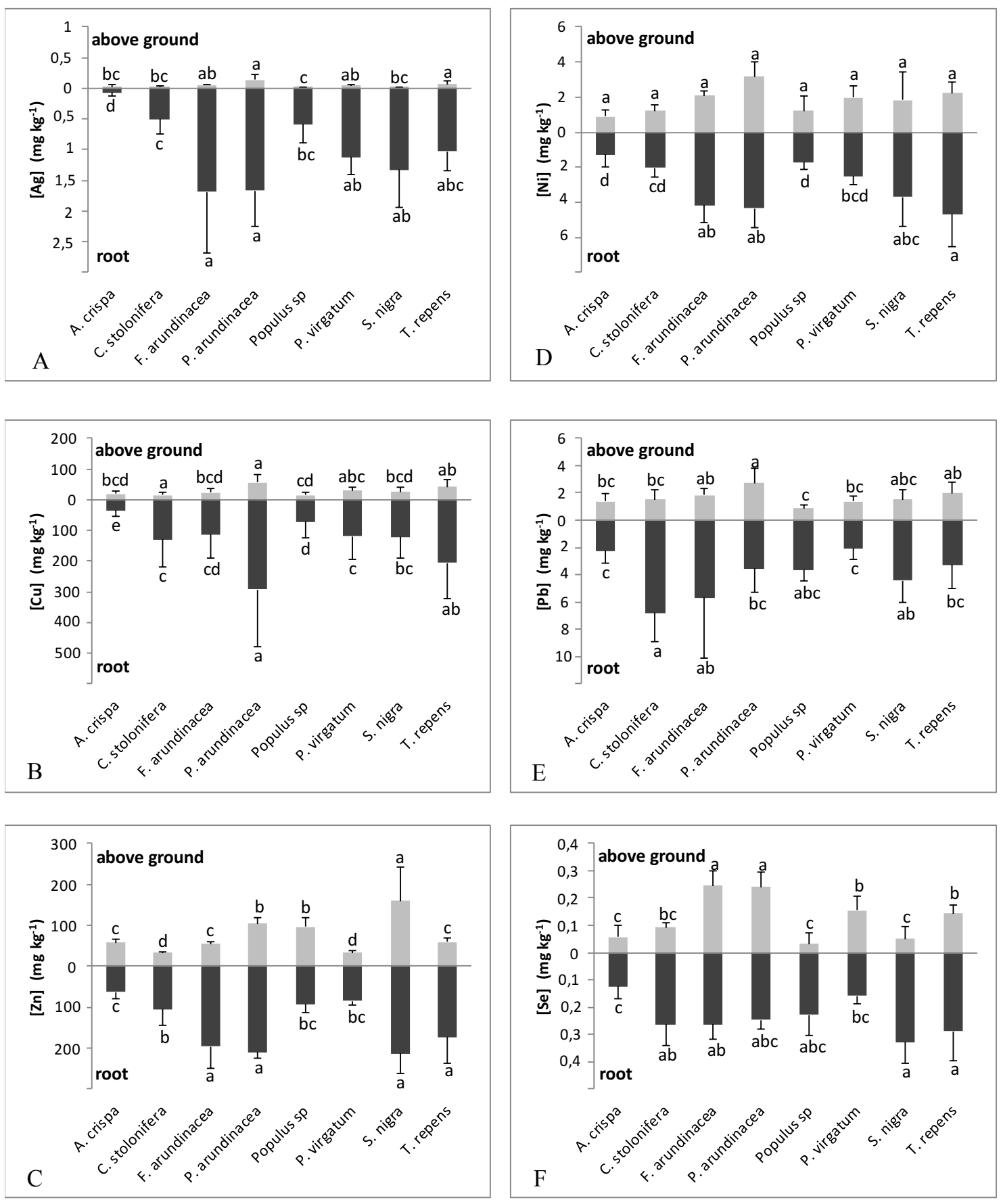
FIGURE 3. Nguyen et al
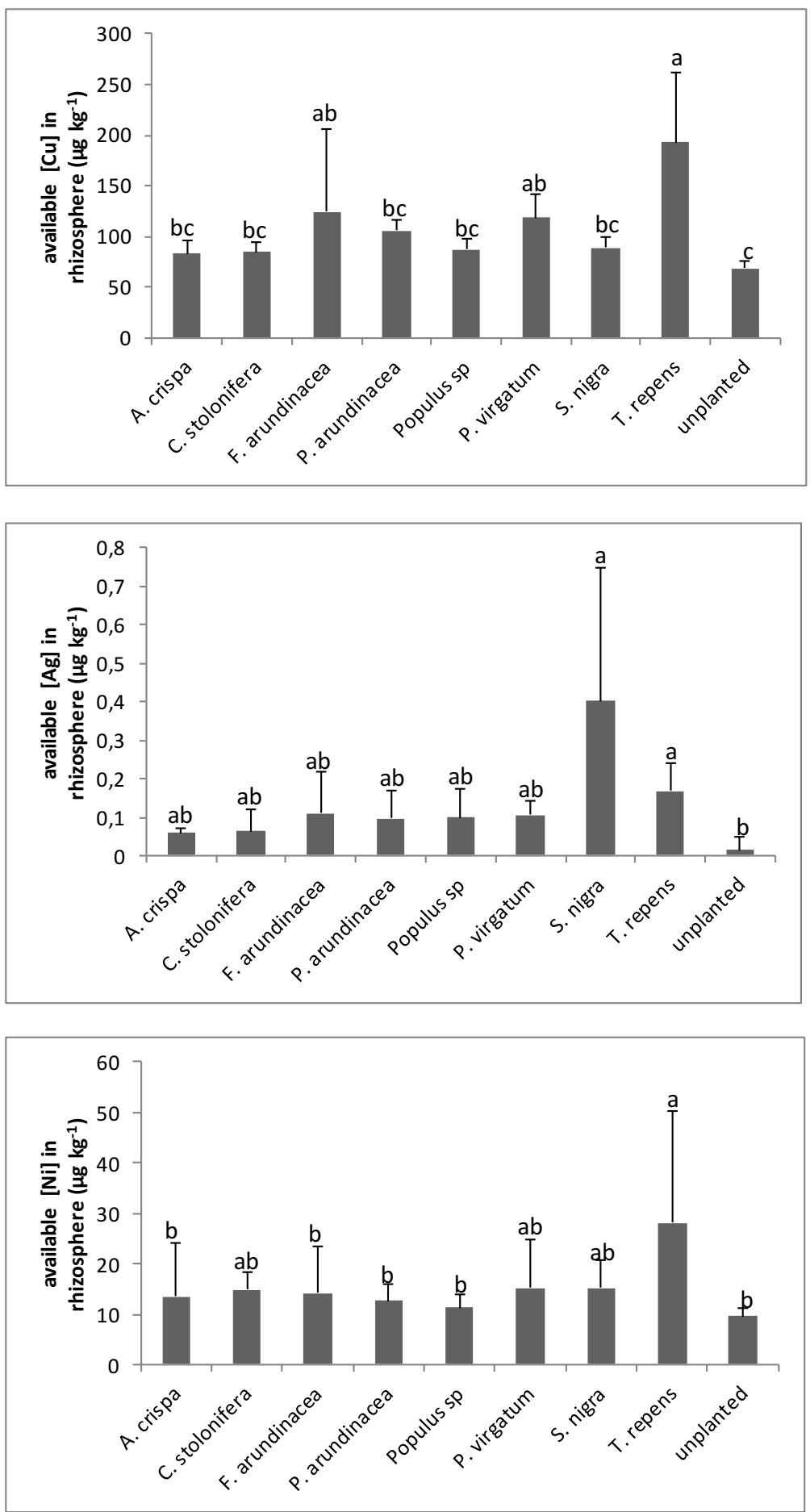


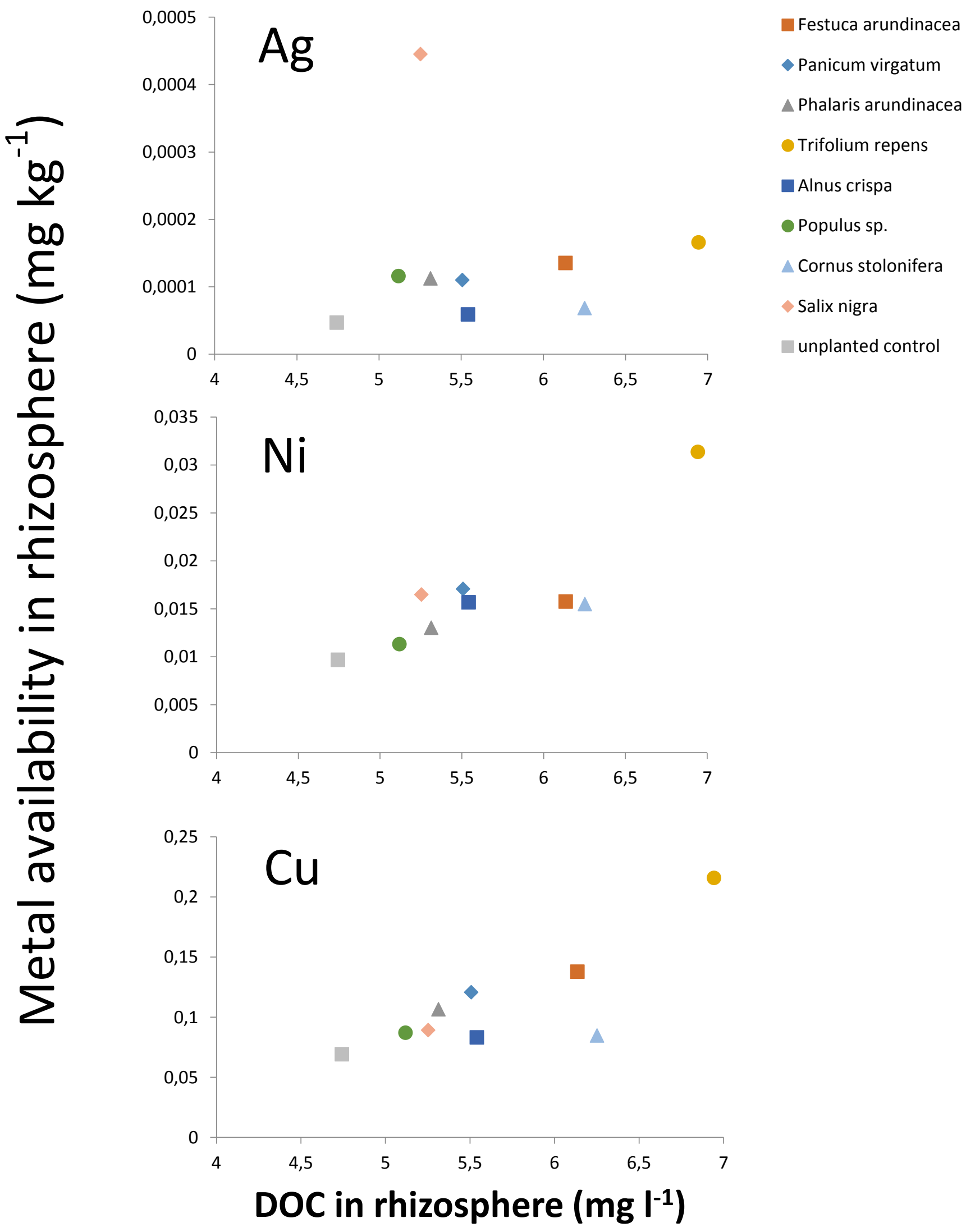

